\title{
Bilateral near total blindness due to miliary neurocysticercosis
}

\author{
Nripen Gaur, ${ }^{1}$ Brijesh Takkar, ${ }^{2}$ Jagjeet Singh, ${ }^{3}$ Pradeep Sharma ${ }^{1}$
}

${ }^{1}$ Department of

Ophthalmology, Dr Rajendra Prasad Centre for Ophthalmic Sciences, All India Institute of Medical Sciences, New Delhi, India

${ }^{2}$ Dr Rajendra Prasad Centre for Ophthalmic Sciences, All India Institute of Medical Sciences, New Delhi, India ${ }^{3}$ Department of Radiology, All India Institute of Medical Sciences, New Delhi, India

\section{Correspondence to}

Professor Pradeep Sharma, drpsharma57@yahoo.com

Accepted 7 March 2017

CrossMark

To cite: Gaur N, Takkar B, Singh J, et al. BMJ Case Rep Published online: [please include Day Month Year] doi:10.1136/bcr-2017219999

\section{DESCRIPTION}

A man aged 18 years presented to our neuro-ophthalmology clinic with symptoms of headache, and painless and gradual onset bilateral visual loss since 2 months. While systemic examination was normal, visual acuity was noted to be perception of light in both eyes. Both pupils reacted sluggishly to light. Both eyes were found to be normal on examination apart from minimal temporal optic disc pallor. Urgent MRI of the head and orbits was ordered, which revealed numerous foci of neurocysticercosis (NCC) scattered throughout the brain parenchyma, giving it a 'starry sky appearance' (figure 1A). The occipital lobe was also found to be studded with such lesions along with surrounding oedema. A prominent cyst, along with scolex, was found to be lodged near the chiasma, compressing it and the emanating optic nerves (figure 1B, C).

Owing to the defective pupil response to light, the visual loss was attributed to occipital and chias$\mathrm{mal} /$ prechiasmal lesions. The patient was started on antihelminthics under the cover of steroids after acquiring a neurologist's opinion. Though headache improved, there was no gain in vision until 2 months of follow-up. Visual evoked potentials were obtained during the therapeutic period which revealed extinguished responses.
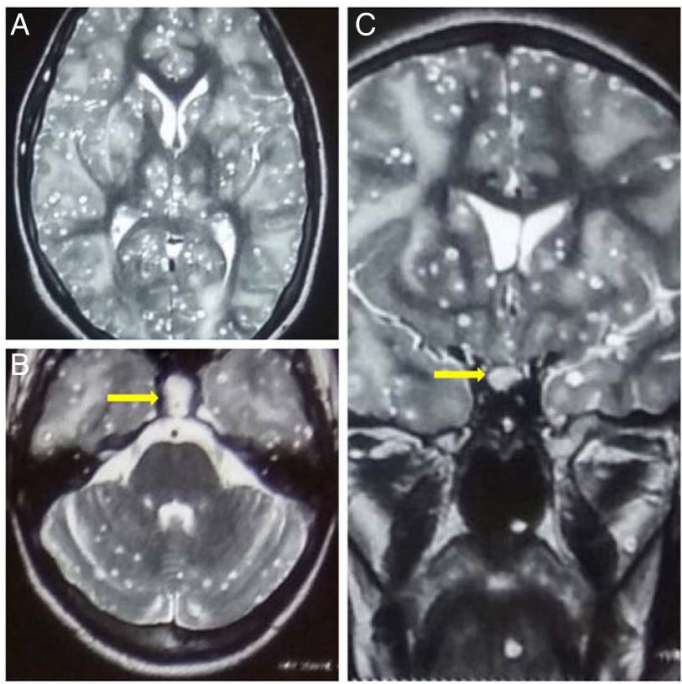

Figure 1 Neuroimaging of miliary neurocysticercosis. (A) T2W axial image showing multiple cystic lesions with eccentric hypointense foci and perilesional oedema scattered diffusely in the brain parenchyma. (B and C) T2W axial and coronal images showing oval cystic lesion (arrow) with hypointense focus in the chiasmatic region causing compression on chiasma and bilateral optic nerves.
Radioimaging is the gold standard for diagnosis of NCC, and stages have been described depending on parenchymal reaction in the brain and calcification changes in the cyst itself. ${ }^{1}$ On imaging, the presence of a 'hole with a dot' appearance due to the scolex is characteristic in early stages. The parasite can also invade the ocular and orbital tissue with/without NCC, and become the cause of visual loss. ${ }^{2}$ Such cases require delicate ocular surgery for removal of the cyst while maintaining the ocular anatomy, whereas management of NCC is predominantly with cysticidal medical therapy. Visual loss due to NCC is a rare cause of its presentation, and more than half of these cases occur secondary to papilloedema and raised intracranial pressure. Chiasmal and retrochisamal lesions account for lesser number of cases. ${ }^{3}$ Inflammation associated with the degenerative cyst, compression due to mass effect, vasculitic infarcts and ictal amaurosis may be the pathogensis behind vision loss due to NCC.

In our case, the blindness occurred irreversibly due to a combination of primary optic atrophy and cortical visual loss. The perichiasmal lesion did not seem large enough to effect blindness due to compression, while the occipital lesions did not explain the poorly reacting pupils by their own virtue. There was no evidence of gross dilation of the cranial ventricles or of secondary optic atrophy in our patient. We infer that an earlier presentation and appropriately timed medical care may have salvaged some vision.

\section{Learning points}

- Neurocysticercosis (NCC) should be considered as a possible cause of neurological deficits in endemic areas.

- Cysticercosis can cause irreversible visual deficits, even leading on to near complete blindness, without invading the eye.

- Treatment delay may be detrimental to visual recovery in cases of visual loss due to NCC.

Contributors BT and NG contributed to diagnosis, workup, writing the manuscript and performing critical revision. JS contributed to diagnosis and management. PS holds the overall responsibility to the presentation, and contributed in diagnosis and performing critical revision of the manuscript.

Competing interests None declared.

Patient consent Obtained.

Provenance and peer review Not commissioned; externally peer reviewed. 


\section{REFERENCES}

1 Coyle CM, Tanowitz HB. Diagnosis and treatment of neurocysticercosis. Interdiscip Perspect Infect Dis 2009;2009:180742.
2 Azad S, Takkar B, Roy S, et al. Pars plana vitrectomy with in vivo cyst lysis for intraocular cysticercosis. Ophthalmic Surg Lasers Imaging Retina 2016;47:665-9.

3 Chang GY, Keane JR. Visual loss in cysticercosis: analysis of 23 patients. Neurology 2001;57:545-8.

Copyright 2017 BMJ Publishing Group. All rights reserved. For permission to reuse any of this content visit

http://group.bmj.com/group/rights-licensing/permissions.

BMJ Case Report Fellows may re-use this article for personal use and teaching without any further permission.

Become a Fellow of BMJ Case Reports today and you can:

- Submit as many cases as you like

- Enjoy fast sympathetic peer review and rapid publication of accepted articles

- Access all the published articles

- Re-use any of the published material for personal use and teaching without further permission

For information on Institutional Fellowships contact consortiasales@bmjgroup.com

Visit casereports.bmj.com for more articles like this and to become a Fellow 